\title{
The Itch-Scratch Cycle: A Review of the Mechanisms
}

\author{
Giulia Rinaldi ${ }^{1}$
}

1 St. George's University \& Hospital of London, UK

Key words: itch, prurigo, scratch, pruritus

Citation: Rinaldi G. The itch-scratch cycle: a review of the mechanisms. Dermatol Pract Concept. 2019;9(2):90-97. DOI: https://doi. org/10.5826/dpc.0902a 03

Accepted: January 28, 2019; Published: April 30, 2019

Copyright: $\odot 2019$ Rinaldi. This is an open-access article distributed under the terms of the Creative Commons Attribution License, which permits unrestricted use, distribution, and reproduction in any medium, provided the original author and source are credited.

Funding: None.

Competing interests: The author has no conflicts of interest to disclose.

Authorship: The author takes responsibility for this publication.

Corresponding author: Giulia Rinaldi, St. George's University \& Hospital of London, Cramer Terrance, London, SW17 0RE, UK.

Email: m1401237@sgul.ac.uk

ABSTRACT Background: Despite being one of the most common presenting dermatological symptoms, itching continues to perplex health care professionals because it is notoriously difficult to control.

Objective: This review gathers evidence to answer the 2-part question, "Why do we itch and scratch?" by exploring the history of itchy disease, the neurobiology of itch, and the 4 different clinical origins of itch: pruritogenic, neurological, neuropathic, and psychological.

Results: The automated scratching reflex and its biological and psychological reasons for existence are complicated and poorly understood. Currently, there are a myriad of treatments available for individuals suffering from this condition; however, many remain symptomatic.

Conclusions: The itch-scratch cycle is a complex pain-like sensation with a reflex-like response. In the future, continued exploration into the mechanisms behind itch and scratch may open the doors for new therapeutic interventions.

\section{Introduction}

In 1660, Hafenreffer wrote, "Itching is an unpleasant cutaneous sensation which provokes the desire to scratch" [1], a definition that not only has remained unchanged for centuries, but also marks itching and scratching as interdependent symptoms. The complex generation of itch and the automatic scratch response lead to the clinically challenging itch-scratch cycle.

In the UK, approximately $80 \%$ of skin-related general practice consultations have itch as an underlying symptom [2]. Despite being one of the most common presenting dermatological symptoms, itching continues to challenge health care professionals because it is notoriously difficult to control [3]. Research continues into fully exposing the origins of this mysterious symptom and is steering its focus toward understanding the mechanisms of chronic itch.

This review attempts to answer the 2-part question, "Why do we itch and scratch?" by first touching on the history of itchy disease, the neurobiology of itch, and the 4 different clinical origins of itch: pruritogenic, neurological, neuropathic, and psychological. In addition, we explore the reflex of scratching and discuss whether it should be deemed a protective mechanism or rather an uncontrollable human impulse that evolution has rendered obsolete. 


\section{A Brief History of Itch}

Itch has troubled humanity throughout history. Dating back to the BC era, ancient Greeks and Egyptians recorded instances of itchy rashes, akin to today's infectious pruritus, that coincided with outbreaks of diarrhea, smallpox, and hookworms [4]. In 121 AD, Roman historian Suetonius also made reference to records of atopic dermatitis. He wrote of Emperor Augustus's atopic symptoms consisting of seasonal allergies, chronic itch, and dry, hardened patches of skin [5]. Subsequently, in 1726, Daniel Turner, the alleged first British dermatologist, described itchiness as a symptom that is "impure," beginning as a contagious process through the skin, which then spreads into the bloodstream [6], possibly reflecting the stark religious influences of 18 thcentury medicine.

In some of the earliest records of modern dermatological medicine, Dr. Hazen (1915) described an impressive array of various skin pathologies, which are much the same as those seen today, however, with the depth of knowledge into their etiology being far more primitive [7]. The symptom of itchiness was habitually mentioned by patients, but its purpose was largely diagnostic in nature. In contrast, itchiness today remains a prominent symptom; however, the focus has shifted away from diagnosis and rather toward management [8-11]. In an effort to successfully manage pruritus, current research has focused on understanding the cellular pathways and the neurobiology of itch, with the objective of identifying target mediators that can be inhibited to relieve itch. For this reason, to answer the question, "Why do we itch?" the following sections will concisely discuss the 4 different underlying etiologies of itch.

\section{Etiology of Itch}

The human etiology of itch can be divided into pruritoceptive (dermatological), neurogenic (systemic), neuropathic, and psychogenic mechanisms $[12,13]$.

\section{Pruritoceptive Itch}

A pruritoceptive, also known as dermatological, itch refers to the cellular mechanisms originating from layers of the skin to produce the somatic sensation of itch [3]. This pathology of itch remains the most common cause of pruritus in dermatology, and a vast amount of research has been done to understand and target therapies against it. Histamine was the first and remains the most explored pruritogen [14-16]; in fact, antihistamines, such as levocetirizine, are often used successfully for the treatment of histamine-induced itch with an observed dose-response pattern [17]. However, antihistamines often give poor relief to chronic itch, for example in atopic dermatitis [18], reinforcing the theory that there are other mediators involved [1,19]. Indeed, mechanisms of dermatological itch are extensive and known to consist of multiple pruritogens, receptors, and chemical signalers [1]; the most common of these are briefly summarized in Table 1. This table uniquely lists pruritogens, their origins, presumed receptors, as well as supportive research, including some potential clinical applicability of this knowledge.

\section{Neurogenic Itch}

Neurogenic itch, sometimes also referred to as systemic itch, is an itch that originates from organs other than the skin, without evidence of peripheral nerve damage or psychiatric roots [3]. Conditions frequently causing neurogenic itch are hematological disease, hepatobiliary disease, and chronic kidney disease [47].

Hematological itch, seen in polycythemia vera, myeloproliferative disorders, or myelofibrosis, is often aquatogenic, occurring after a warm shower. Indeed, this itch is shown to be subdued by selective serotonin reuptake inhibitors; this response is hypothesized to be due to the upregulation of serotonin receptors creating a higher activation threshold; however, a confirmed mechanism is unknown [42,45,48].

Cholestatic pruritus, seen in a variety of hepatocellular disorders, is thought to be due to the accumulation of bile salts that trigger histamine and lysophosphatidic acid release [49]. Lysophosphatidic acid is a powerful pruritogen as seen by the correlation between high serum levels and pruritus in patients [49-51]. Furthermore, cholestatic patients also have higher levels of endogenous opioids, possibly produced by the diseased liver and thought to contribute to systemic itch [52]. Indeed, administration of oral or intravenous opioid antagonists has been shown to significantly reduce scores on visual analogue scales of pruritus in patients with hepatobiliary disease [53-55].

Similarly, more than $40 \%$ of patients with chronic kidney disease present with pruritus thought to originate from endogenous opioid upregulation [56]. Therefore, opioid antagonist therapies are trialed; however, higher quality trials are still needed to confirm the efficacy, safety, and addictive risks of these treatments [28,57-59].

\section{Neuropathic Itch}

The third etiology of itch is neuropathic, which refers to a neuronal origin of itch, occurring due to damaged central or peripheral afferent nerves. This type of itch is often accompanied by localized neuropathic symptoms, such as pain and paresthesia, or as part of a larger neurological diagnosis, such as multiple sclerosis $[3,60]$. The mechanisms of this itch are often debated between erroneous stimulation of pruritic signals or damage of itch-inhibiting neurons [3]. Overall, neuropathic itch presents in a variety of ways, from 
Table 1. Physiology of Pruritoceptive Itch

\begin{tabular}{|c|c|c|c|c|}
\hline & Pruritogens & Origin & $\begin{array}{l}\text { Receptors \& } \\
\text { Mediators }\end{array}$ & Clinical Applicability \\
\hline \multirow[t]{9}{*}{ Peripheral } & Histamine & Mast cells & H1 \& H4, TRPV1 & $\begin{array}{l}\text { H1 \& H4 antagonists show benefit in reducing } \\
\text { pruritus both in chronic itch and in patients with } \\
\text { atopic dermatitis [20-22] }\end{array}$ \\
\hline & Tryptase & Mast cells & \multirow{3}{*}{$\begin{array}{l}\text { PAR2, PAR4 [3] } \\
\text { TRPV1, BNP }\end{array}$} & \multirow{3}{*}{$\begin{array}{l}\text { PAR2 upregulated in atopic dermatitis [23] \& causes } \\
\text { an itch without wheal [24]; PAR2 antagonists could } \\
\text { combat chronic nonhistaminic itch [25]; removal } \\
\text { of TRPV1 ion channel and BNP from neurons } \\
\text { suppressed itch in mice [26] }\end{array}$} \\
\hline & Mucunain & Cowhage & & \\
\hline & Dust mites & Mites & & \\
\hline & Capsaicin & Chili & TRPV1 [1] & $\begin{array}{l}\text { Topical capsaicin reduced itch in chronic psoriasis } \\
\text { [27], uremic patients [28], and hemodialysis attenders } \\
\text { [29]; the capsaicin } 8 \% \text { patch has also shown success } \\
\text { in addressing neurogenic itch such as brachioradial } \\
\text { pruritus and meralgia paresthetica [30] }\end{array}$ \\
\hline & Endothelin 1 & Endothelium & $\mathrm{ET}(\mathrm{A}), \mathrm{ET}(\mathrm{B})[31]$ & Upregulated in chronic itch patients [31] \\
\hline & Cytokines & TH2 cells & $\begin{array}{l}\text { IL-31, IL-31RA, } \\
\text { OSMR [32] }\end{array}$ & $\begin{array}{l}\text { IL-31 induces itch in mice [33]; anti-IL-31 shown to } \\
\text { reduce itch in atopic dermatitis patients [34] }\end{array}$ \\
\hline & Kallikrein 5 & Epithelium & PAR2 [35] & $\begin{array}{l}\text { Increased scratching in mice with increased kallikrein } \\
5 \text { expression }[35,36]\end{array}$ \\
\hline & Substance P & $\begin{array}{l}\text { Afferent } \\
\text { neurons }\end{array}$ & NK1 [37] & $\begin{array}{l}\text { Substance P levels involved in atopic dermatitis } \\
\text { pathophysiology [38,39]; TRPV1 agonists shown to } \\
\text { deplete substance P levels peripherally [1]; substance P } \\
\text { elevated in prurigo nodularis patients [40] }\end{array}$ \\
\hline \multirow[t]{2}{*}{ Central } & Opioids & $\begin{array}{l}\text { Exogenous } \\
\text { neurons \& } \\
\text { keratinocytes }\end{array}$ & $\mu$ - \& $\kappa$-receptors & $\begin{array}{l}\text { Morphine induces scratching and } \mu \text {-opioid antagonist } \\
\text { shown to relieve chronic itch [41] }\end{array}$ \\
\hline & $5-\mathrm{HT}$ & $5-\mathrm{HT}$ & TRPV1 & $\begin{array}{l}\text { Involved in polycythemia vera } \& \text { cholestasis itch } \\
\text { [42]; more pruritogenic than histamine in rats [43]; } \\
\text { serotonin injection induces pruritus in healthy patients } \\
\text { [44]; SSRIs shown to reduce chronic itch [45]; } \\
\text { ondansetron effective in cholestatic itch [46] }\end{array}$ \\
\hline
\end{tabular}

5-HT = serotonin; $\mathrm{BNP}=$ type $\mathrm{b}$ natriuretic polypeptide; $\mathrm{ET}$ = endothelin; IL-31RA = interleukin-31 receptor A; NK1 = neurokinin 1; OSMR = oncostatin $\mathrm{M}$ receptor; PAR= protease activated receptors; $\mathrm{SSRI}=$ selective serotonin reuptake inhibitor; TRPV1 = transient receptor potential villanoid 1.

postherpetic to brachioradial pruritus. As such, neurologists should be involved to confirm the neuropathological diagnosis of itch [60]. This itch is perhaps the most overlooked by researchers and dermatologists as it can be easily labeled as a defective neuropathic stimulus and passed to neurologists for treatment. Nevertheless, collaboration between dermatologists and neurologists has optimistically led to the trial of neuropathic medications, such as gabapentin, to treat different etiologies of chronic itch with promising results [61-63].

\section{Psychogenic Itch}

Psychogenic itch, the fourth etiology of itch, is a diagnosis of exclusion whereby another reason for itch is not found and mental health symptoms are present [3]. Psychogenic itch can often present with a psychiatric condition such as parasitosis hallucinations, depression, or compulsive scratching syndromes. At other times, it can coincide with lifestyle stress which exacerbates itchy pathologies such as eczema, urticaria, and psoriasis $[64,65]$. The pathophysiology behind psychogenic itch is uncertain; however, imbalances in serotonin, opioids, and dopamine may play a part. Opioids have been shown to mediate responses to social pain and opioid receptor modulators are now being explored as antidepressants; however, their concomitant addictiveness has delayed their clinical use [66-68]. Furthermore, patients with depressive disorders have been shown to have elevated levels of the pruritogen substance $\mathrm{P}$ in their cerebrospinal fluid [68]. The evidence above suggests that the origin of itch in patients with psychiatric conditions is not purely an illusion of the mind, rather, a true stimulation of their afferent itch fibers due to a possible inherent imbalance of central pruritogens. 


\section{Neurobiology of Itch}

As shown above, itch is triggered by 4 distinct mechanisms either centrally or peripherally. To understand how pruritogenic stimulation is transmitted to the brain and interpreted, we must study the different afferent (mechanical, thermal, and polymodal) neurons, how they respond to pruritogens, and which parts of the cortex they activate [69-72].

Previously, itch was believed to be a mild form of pain transmitted by the same nociceptive fibers and suppressed by greater painful (mechanical or thermal) stimuli [73]. This "intensivity" theory was later discredited by evidence from both humans and animals. Not only did increasing the intensity of an itchy stimulus not convert to a painful stimulus, but also a distinct subpopulation of nerves were shown to be activated by pruritogenic vs painful stimuli [74-76]. Similarly, itch triggers a targeted scratch response, while pain generates an unrelated withdrawal reaction, suggesting itch and pain are not transmitted via identical neurological pathways.

Currently, newer theories exist about how itch is transmitted to the brain, specifically the "selectivity" and "labeledline" theories. The "selectivity" theory states that itch fibers are more selective toward pruritogenic stimuli, but are polymodal, also transmitting pain. In contrast, the "labeled-line" theory supports the existence of afferent fibers exclusively responsive to pruritogenic stimuli [3]. To explore both theories, research has used animal experiments to alter the expression of presumed pruritoceptive mediators and evaluate variations in scratch response [77-83].

Cats have been shown to have afferent nerve fibers solely activated by pruritogens both peripherally and in the spinothalamic tract [84]. Moreover, mice possess afferent neurons expressing specific pruritogenic modulators such as Mas-related-G-protein-coupled receptor (MrgprA3+) and gastrin-related peptide (GRP), the latter expressed only in a small subset of dorsal ganglia and in the lamina I tract of the spinothalamic cord $[85,86]$. The genetic removal of these receptors significantly reduces the scratch response, but not pain response. This evidence essentially supports that in animals itch is probably mediated via the "labeled-line" theory and that their itch and pain neurons are distinct $[86,87]$.

In humans, more than $90 \%$ of afferent fibers are polymodal; they respond to 2 or more types of stimuli $[75,88]$. Skin stimulation has shown that different fibers responded to histamine and non-histamine-induced itch, suggesting that humans possess distinctive peripheral pathways for the transmission of different pruritogens [89,90]. These fibers have been shown to go on to activate separate subsets of the spinothalamic tract; however, all these pruritogenic pathways were also activated by painful stimuli [91,92]. This finding suggests that in humans, itch is probably transmitted in line with the "selectivity theory" using polymodal fibers, which can transmit both pain and itch. If itch fibers in humans are polymodal, pain and itch must be differentiated more proximally; in fact, functional magnetic resonance imaging of the cortex has shown different activation areas [93,94]. Owing to the unethical nature of isolating spinothalamic sections in humans, unanswered questions remain about the role central ascending tracts partake in the perception of itch [95]. Nonetheless, knowledge that itch is transmitted by polymodal fibers is useful for the discovery of new therapies to combat chronic itch by trialing treatments used to break other hypersensitivities such as chronic pain or chronic cough cycles $[61,62,96]$.

Pathways of itch conduction and perception vary between humans and animals, suggesting that evolution may have devolved our separate pathway for itch. This could mean that itching may have been beneficial in animals who needed to "scratch-away" invaders (such as ticks and fleas) from their fur coat, a response that was no longer necessary once we had lost our primate-like hairy coat. This would explain why scratching can often be traumatic to human skin, whereas in furred animals it is required to rid the hairs of invaders and does not often damage their underlying skin.

\section{Scratching}

Scratching is often presumed to provide mechanical protection and subsequent inflammatory defense against harmful elements on the skin $[97,98]$. However, scratching is also known to disrupt the epidermal barrier and facilitate infection [11]. Another view is that we scratch because we want to relieve the itch by causing localized pain that will suppress the intolerable itch, suggesting we prefer to withstand mild pain rather than be itchy [98]. Moreover, relieving an itch via scratching often causes a feeling of pleasure, thought to be due to both the riddance of the intolerable itch and the release of serotonin during scratching [99].

Although our body seems to be "rewarded" for scratching an itch, it is well known that repeated scratching prolongs and aggravates the itch in various situations ranging from mosquito bites to atopic dermatitis [100]. Indeed, itchy stimuli activate the striatum and limbic region of the cortex, the reward and motivation centers, causing a reward-driven but altogether damaging itch-scratch cycle [101]. In addition, when we advise patients to stop scratching, we are fundamentally implying that the human scratch response is innately flawed. Patients aware of this detrimental itchscratch cycle continue to scratch, knowing it will only provide short-term relief.

Scratching has been reported to increase at night due to itch being exacerbated by higher circadian skin temperatures, increased trans-epidermal water losses, reduced corticosteroid 
anti-inflammatory levels, and a disinhibited scratch response $[102,103]$. Times of unawareness, such as sleep, may result in uncontrolled scratching leading to greater dermatological inflammation and individual awakening. The consequences of chronic sleep insufficiency can be debilitating to an individual's mental function, physical energy, and long-term health; individuals with chronic sleep deficiency have an increased chance of depression, obesity, and smoking, and a reduced life expectancy due to various general medical causes [104,105].

Ultimately, pain and itch differ in the responses they provoke; pain causes a withdrawal response, telling our body to rest, hold, or hide the affected area from external stimuli. On the contrary, itch causes the scratch response, an attentiondrawing reflex, which tells us to topically injure that area. Would we be healthier in a scratch-free world?

\section{Management of Pruritus}

The management of pruritus is evolving toward targeted therapies tackling specific etiologies of itch. Before initiating treatment, patients with itch of unknown origin should undergo a thorough medical history and examination. The severity of pruritus should be assessed using an official quality-of-life tool such as the Visual Analogue Scales and Dermatology Life Quality Index [106,107]. The British Association of Dermatology recommends initial blood tests including full blood cell count, iron levels, thyroid function tests, urea and electrolyte levels, liver function tests, and an autoimmune screen [108]. This will help diagnose or exclude hematological malignancy, iron deficiency or overload, thyroid disease, uremia, hepatic pruritus, or autoimmune disease among systemic causes of itch [28,56,109-112]. Further investigations such as imaging and skin biopsies can be obtained if rarer causes of itch, for example paraneoplastic syndromes, or dermatosis is suspected.

Pruritoceptive itch, if thought to be triggered by skin barrier flaws or dermatological disease, will most often be controlled via topical treatments targeting the specific skin condition and using intensive skin moisturizing regimens [17]. Dermatological itch of urticarial origin, thought to arise from histamine release, is most often controlled with oral high-dose antihistamines, intermittent steroids, or, in refractory cases, the biological anti-IgE omalizumab $[17,113]$. In refractory dermatological pruritus, disease-specific interventions, for example narrow-band phototherapy in psoriasis, can control flares; however, this must be balanced with the long-term risks of skin malignancy [114].

Specific subtypes of itch can also be managed using therapies that directly target their transmission pathways. Uremic pruritus has been successfully controlled using topical capsaicin or oral gabapentin $[28,59]$. Nocturnal and hemato- logical pruritus can often be subdued by the use of tricyclic antidepressants or selective serotonin reuptake inhibitors, both by encouraging sleep and upregulating serotonin receptors, contributing to itch signal transmission [42,45,115]. In severe cases of chronic pruritus, novel systemic therapies can be considered. Neurokinin 1 receptor antagonists and anti-interleukin 31 have shown promising results in battling chronic pruritus, with the latter showing significant reduction in pruritus scores and body surface areas affected by atopic dermatitis [115-118]. Neurokinin 1 antagonists, mediating the substance P pathway, have recently shown a dose-dependent decrease of baseline pruritic visual analogue scales after a few weeks of use $[119,120]$. In atopic dermatitis, monoclonal antibodies targeting interleukin 4 and 13 have also shown promise in increasing the quality of life of patients through itch reduction [121]. These innovative therapies to combat itch are being revealed thanks to an increased understanding of its different pathways and transmitters. Nevertheless, additional data are required to explore the success rates, cost-effectiveness, and long-term adverse effects of innovative therapies in patients suffering from chronic itch.

\section{Conclusions}

An itch can arise from a variety of underlying mechanisms and is transmitted to the cortex via a subset of polymodal fibers that are more selective toward pruritogens. Pruritic skin conditions continue to compromise a large psychological and financial burden, with up to $20 \%$ of children in Britain suffering from eczema [122] and 3\% of adults from psoriasis. These conditions have a significant psychological influence, proven akin to that of chronic pain, with $10 \%$ of patients with chronic psoriasis, hand eczema, or atopic dermatitis exhibiting signs of clinical depression [8,123]. Evolutionally, the benefit of itch is thought to be the accompanying scratch which removes harmful elements from skin or fur; however, in chronic pruritic conditions this often leads to a detrimental cycle of skin changes and further scratching. Therefore, could the benefits of itch just be a remnant from our fur-coated ancestors? As we are currently unable to remove this seemingly unnecessary response from our genes, we must focus on providing safe and successful itch relief for people suffering from debilitating chronic itchy conditions. The failure to do so may leave us with an itch that we just must scratch.

\section{References}

1. Ikoma A, Steinhoff M, Ständer S, Yosipovitch G, Schmelz M. The neurobiology of itch. Nat Rev Neurosci. 2006;7(7):535-547.

2. von Hospenthal T. Lessons for the NHS: Commissioning a Dermatology Service. Based on Case Studies from England. British Association of Dermatologists. 2013. Available from: https://www. 
bad.org.uk/shared/get-file.ashx?itemtype=document\&id=1009. Accessed January 4, 2018.

3. Garibyan L, Rheingold CG, Lerner EA. Understanding the pathophysiology of itch. Dermatol Ther. 2013;26(2):84-91.

4. Nelson KE, Masters Williams CF. Infectious Disease Epidemiology: Theory and Practice. Boston: Jones and Bartlett Publishers; 2001:1-29.

5. Suetonius. The Twelve Caesars. Graves R, ed. Penguin Classics; 2007, 95 pp.

6. Lyell A. Daniel Turner (1667-1740) LRCP London (1711) M.D. honorary, Yale (1723) surgeon, physician and pioneer dermatologist. Int J Dermatol. 1982;21(3):162-170.

7. Hazen HH. Diseases of the Skin. St Louis: CV Mosby; 1915. Available from: https://archive.org/details/diseasesskin00haze goog. Accessed January 4, 2018.

8. Kini SP, DeLong LK, Veledar E, McKenzie-Brown AM, Schaufele M, Chen SC. The impact of pruritus on quality of life: the skin equivalent of pain. Arch Dermatol. 2011;147(10):1153-1156.

9. Zachariae R, Lei U, Haedersdal M, Zachariae C. Itch severity and quality of life in patients with pruritus: preliminary validity of a Danish adaptation of the itch severity scale. Acta Derm Venereol. 2012;92(5):508-514.

10. Erturk IE, Arican O, Omurlu IK, Sut N. Effect of the pruritus on the quality of life: a preliminary study. Ann Dermatol. 2012;24(4):406-412.

11. Hong J, Buddenkotte J, Berger TG, Steinhoff M. Management of itch in atopic dermatitis. Semin Cutan Med Surg. 2011;30(2):7186.

12. Yosipovitch G, Greaves MW, Schmelz M. Itch. Lancet. 2003;361(9358):690-694.

13. Bernhard JD. Itch and pruritus: what are they, and how should itches be classified? Dermatol Ther. 2005;18(4):288-291.

14. Broadbent JL. Observations on histamine-induced pruritus and pain. Br J Pharmacol Chemother. 1955;10(2):183-185.

15. Shim WS, Oh U. Histamine-induced itch and its relationship with pain. Mol Pain. 2008;4:29.

16. Quilliam JP. Substances producing pain and Itch. Proc R Soc Med. 1965;58(3):215-216.

17. Bulca S, Bayramgurler D, Odyakmaz Demirsoy E, et al. Comparison of effects of 5 and $10 \mathrm{mg}$ oral desloratadine and levocetirizine on histamine-induced wheal and flare response in healthy volunteers. J Dermatolog Treat. 2013;24(6):473-476.

18. Klein PA, Clark RA. An evidence-based review of the efficacy of antihistamines in relieving pruritus in atopic dermatitis. Arch Dermatol. 1999;135(12):1522-1525.

19. Han L, Dong X. Itch mechanisms and circuits. Annu Rev Biophys. 2014;43:331-355.

20. Murata Y, Song M, Kikuchi H, et al. Phase 2a, randomized, double-blind, placebo-controlled, multicenter, parallel-group study of a H4 R-antagonist (JNJ-39758979) in Japanese adults with moderate atopic dermatitis. J Dermatol. 2015;42(2):129-139.

21. Grundmann S, Ständer S. Chronic pruritus: clinics and treatment. Ann Dermatol. 2011;23(1):1-11.

22. Imaizumi A, Kawakami T, Murakami F, Soma Y, Mizoguchi M. Effective treatment of pruritus in atopic dermatitis using $\mathrm{H} 1$ antihistamines (second-generation antihistamines): changes in blood histamine and tryptase levels. J Dermatol Sci. 2003;33(1):23-29.

23. Steinhoff M, Neisius U, Ikoma A, et al. Proteinase-activated receptor-2 mediates itch: a novel pathway for pruritus in human skin. J Neurosci. 2003;23(15):6176-6180.
24. Sikand P, Shimada SG, Green BG, LaMotte RH. Similar itch and nociceptive sensations evoked by punctate cutaneous application of capsaicin, histamine and cowhage. Pain. 2009;144(1-2):66-75.

25. Andoh T, Kuraishi Y. Antipruritic mechanisms of topical E6005, a phosphodiesterase 4 inhibitor: inhibition of responses to proteinase-activated receptor 2 stimulation mediated by increase in intracellular cyclic AMP. J Dermatol Sci. 2014;76(3):206-213.

26. Mishra SK, Hoon MA. The cells and circuitry for itch responses in mice. Science. 2013;340(6135):968-971.

27. Ellis CN, Berberian B, Sulica VI, et al. A double-blind evaluation of topical capsaicin in pruritic psoriasis. J Am Acad Dermatol. 1993;29(3):438-442.

28. Simonsen E, Komenda P, Lerner B, et al. Treatment of uremic pruritus: a systematic review. Am J Kidney Dis. 2017;70(5):638-655.

29. Breneman DL, Cardone JS, Blumsack RF, Lather RM, Searle EA, Pollack VE. Topical capsaicin for treatment of hemodialysisrelated pruritus. J Am Acad Dermatol. 1992;26(1):91-94.

30. Pereira MP, Luling H, Dieckhofer A, Steinke S, Zeidler C, Ständer S. Brachioradial pruritus and notalgia paraesthetica: a comparative observational study of clinical presentation and morphological pathologies. Acta Derm Venereol. 2018;98(1):82-88.

31. Kido-Nakahara M, Buddenkotte J, Kempkes C, et al. Neural peptidase endothelin-converting enzyme 1 regulates endothelin 1-induced pruritus. J Clin Invest. 2014;124(6):2683-2695.

32. Paus R, Schmelz M, Bíró T, Steinhoff M. Frontiers in pruritus research: scratching the brain for more effective itch therapy. $J$ Clin Invest. 2006;116(5):1174-1186.

33. Arai I, Tsuji M, Takeda H, Akiyama N, Saito S. A single dose of interleukin-31 (IL-31) causes continuous itch-associated scratching behaviour in mice. Exp Dermatol. 2013;22(10):669-671.

34. Furue M, Yamamura K, Kido-Nakahara M, Nakahara T, Fukui Y. Emerging role of interleukin-31 and interleukin-31 receptor in pruritus in atopic dermatitis. Allergy. 2018;73(1):29-36.

35. Jang $\mathrm{H}$, Matsuda A, Jung $\mathrm{K}$, et al. Skin $\mathrm{pH}$ is the master switch of kallikrein 5-mediated skin barrier destruction in a murine atopic dermatitis model. J Invest Dermatol. 2016;136(1):127-135.

36. Furio L, de Veer S, Jaillet M, et al. Transgenic kallikrein 5 mice reproduce major cutaneous and systemic hallmarks of Netherton syndrome. J Exp Med. 2014;211(3):499-513.

37. Carstens EE, Carstens MI, Simons CT, Jinks SL. Dorsal horn neurons expressing NK-1 receptors mediate scratching in rats. Neuroreport. 2010;21(4):303-308.

38. Toyoda M, Nakamura M, Makino T, Hino T, Kagoura M, Morohashi M. Nerve growth factor and substance $\mathrm{P}$ are useful plasma markers of disease activity in atopic dermatitis. $\mathrm{Br} J$ Dermatol. 2002;147(1):71-9.

39. Zhang Z, Zheng W, Xie H, et al. Up-regulated expression of substance P in CD8+ T cells and NK1R on monocytes of atopic dermatitis. J Transl Med. 2017;15(1):93.

40. Lee MR, Shumack S. Prurigo nodularis: a review. Australas J Dermatol. 2005;46(4):211-220.

41. Liu XY, Liu ZC, Sun YG, et al. Unidirectional cross-activation of GRPR by MOR1D uncouples itch and analgesia induced by opioids. Cell. 2011;147(2):447-458.

42. Tefferi A, Fonseca R. Selective serotonin reuptake inhibitors are effective in the treatment of polycythemia vera-associated pruritus. Blood. 2002;99(1):2627.

43. Jinks SL, Carstens E. Responses of superficial dorsal horn neurons to intradermal serotonin and other irritants: comparison with scratching behavior. J Neurophysiol. 2002;87(3):1280-1289. 
44. Rausl A, Nordlind K, Wahlgren CF. Pruritic and vascular responses induced by serotonin in patients with atopic dermatitis and in healthy controls. Acta Derm Venereol. 2013;93(3):277-280.

45. Stander S, Bockenholt B, Schurmeyer-Horst F, et al. Treatment of chronic pruritus with the selective serotonin re-uptake inhibitors paroxetine and fluvoxamine: results of an open-labelled, two-arm proof-of-concept study. Acta Derm Venereol. 2009;89(1):45-51.

46. Schworer H, Hartmann H, Ramadori G. Relief of cholestatic pruritus by a novel class of drugs: 5-hydroxytryptamine type 3 (5-HT3) receptor antagonists: effectiveness of ondansetron. Pain. 1995;61(1):33-37.

47. Kremer AE, Feramisco J, Reeh PW, Beuers U, Oude Elferink RPJ. Receptors, cells and circuits involved in pruritus of systemic disorders. Biochim Biophys Acta. 2014;1842(7):869-892.

48. Gupta MA, Guptat AK. The use of antidepressant drugs in dermatology. J Eur Acad Dermatol Venereol. 2001;15(6):512-518.

49. Kremer AE, Martens JJWW, Kulik W, et al. Lysophosphatidic acid is a potential mediator of cholestatic pruritus. Gastroenterology. 2010;139(3):1008-1018, 1018.e1.

50. Kremer AE, Gonzales E, Schaap FG, Oude Elferink RPJ, Jacque$\min$ E, Beuers U. Serum autotaxin activity correlates with pruritus in pediatric cholestatic disorders. J Pediatr Gastroenterol Nutr. 2016;62(4):530-535.

51. Kremer AE, van Dijk R, Leckie P, et al. Serum autotaxin is increased in pruritus of cholestasis, but not of other origin, and responds to therapeutic interventions. Hepatology. 2012;56(4):1391-1400.

52. Thornton JR, Losowsky MS. Opioid peptides and primary biliary cirrhosis. BMJ. 1988;297(6662):1501-1504.

53. Bergasa NV, Talbot TL, Alling DW, et al. A controlled trial of naloxone infusions for the pruritus of chronic cholestasis. Gastroenterology. 1992;102(2):544-549.

54. Joshi GG, Thakur BS, Sircar S, Namdeo A, Jain AK. Role of intravenous naloxone in severe pruritus of acute cholestasis. Indian J Gastroenterol. 2009;28(5):180-182.

55. Mansour-Ghanaei F, Taheri A, Froutan H, et al. Effect of oral naltrexone on pruritus in cholestatic patients. World J Gastroenterol. 2006;12(7):1125-1128

56. Combs SA, Teixeira JP, Germain MJ. Pruritus in kidney disease. Semin Nephrol. 2015;35(4):383-391.

57. Kumagai H, Ebata T, Takamori K, et al. Efficacy and safety of a novel $\mathrm{k}$-agonist for managing intractable pruritus in dialysis patients. Am J Nephrol. 2012;36(2):175-183.

58. Solak Y, Biyik Z, Atalay H, et al. Pregabalin versus gabapentin in the treatment of neuropathic pruritus in maintenance haemodialysis patients: a prospective, crossover study. Nephrology (Carlton). 2012;17(8):710-717.

59. Lau T, Leung S, Lau W. Gabapentin for uremic pruritus in hemodialysis patients: a qualitative systematic review. Can J Kidney Health Dis. 2016;3:14.

60. Stumpf A, Ständer S. Neuropathic itch: diagnosis and management. Dermatol Ther. 2013;26(2):104-109.

61. Maciel AAW, Cunha PR, Laraia IO, Trevisan F. Efficacy of gabapentin in the improvement of pruritus and quality of life of patients with notalgia paresthetica. An Bras Dermatol. 2014;89(4):570-575.

62. PD Y, NE W. Efficacy of gabapentin in the management of pruritus of unknown origin. Arch Dermatol. 2005;141(12):15071509.

63. Oaklander AL. Neuropathic itch. Semin Cutan Med Surg. 2011;30(2):87-92.
64. Suárez AL, Feramisco JD, Koo J, Steinhoff M. Psychoneuroimmunology of psychological stress and atopic dermatitis: pathophysiologic and therapeutic updates. Acta Derm Venereol. 2012;92(1):7-15.

65. Schut C, Bosbach S, Gieler U, Kupfer J. Personality traits, depression and itch in patients with atopic dermatitis in an experimental setting: a regression analysis. Acta Derm Venereol. 2014;94(1):20-25.

66. Hsu DT, Sanford BJ, Meyers KK, et al. Response of the $\mu$-opioid system to social rejection and acceptance. Mol Psychiatry. 2013;18(11):1211-1217.

67. Lutz P-E, Kieffer BL. Opioid receptors: distinct roles in mood disorders. Trends Neurosci. 2013;36(3):195-206.

68. Ehrich E, Turncliff R, Du Y, et al. Evaluation of opioid modulation in major depressive disorder. Neuropsychopharmacology. 2015;40(6):1448-1455.

69. Geracioti TDJ, Carpenter LL, Owens MJ, et al. Elevated cerebrospinal fluid substance $\mathrm{p}$ concentrations in posttraumatic stress disorder and major depression. Am J Psychiatry. 2006;163(4):637643.

70. Dubin AE, Patapoutian A. Nociceptors: the sensors of the pain pathway. J Clin Invest. 2010;120(11):3760-3772.

71. Lawson SN. Phenotype and function of somatic primary afferent nociceptive neurones with C-, A $\delta$ - or Aa/ $\beta$-fibres. Exp Physiol. 2002;87(2):239-244.

72. Basbaum AI, Bautista DM, Scherrer G, Julius D. Cellular and molecular mechanisms of pain. Cell. 2009;139(2):267-284.

73. Ward L, Wright E, McMahon SB. A comparison of the effects of noxious and innocuous counterstimuli on experimentally induced itch and pain. Pain. 1996;64(1):129-138.

74. Tuckett RP. Itch evoked by electrical stimulation of the skin. $J$ Invest Dermatol. 1982;79(6):368-373.

75. Handwerker HO, Forster C, Kirchhoff C. Discharge patterns of human C-fibers induced by itching and burning stimuli. J Neurophysiol. 1991;66(1):307-315.

76. Ochoa J, Torebjork E. Sensations evoked by intraneural microstimulation of C nociceptor fibres in human skin nerves.J Physiol. 1989;415:583-599.

77. Miyamoto T, Nojima H, Shinkado T, Nakahashi T, Kuraishi Y. Itch-associated response induced by experimental dry skin in mice. Jpn J Pharmacol. 2002;88(3):285-292.

78. Yu YQ, Barry DM, Hao Y, Liu XT, Chen ZF. Molecular and neural basis of contagious itch behavior in mice. Science. 2017;355(6329):1072-1076.

79. Wilson SR, Nelson AM, Batia L, et al. The ion channel TRPA1 is required for chronic itch. J Neurosci. 2013;33(22):9283-9294.

80. Spradley JM, Davoodi A, Carstens MI, Carstens E. Opioid modulation of facial itch- and pain-related responses and grooming behavior in rats. Acta Derm Venereol. 2012;92(5):515-520.

81. Matesic LE, Copeland NG, Jenkins NA. Itchy mice: the identification of a new pathway for the development of autoimmunity. Curr Top Microbiol Immunol. 2008;321:185-200.

82. Shimada SG, LaMotte RH. Behavioral differentiation between itch and pain in mouse. Pain. 2008;139(3):681-387.

83. Kuraishi Y, Nagasawa T, Hayashi K, Satoh M. Scratching behavior induced by pruritogenic but not algesiogenic agents in mice. Eur J Pharmacol. 1995;275(3):229-233.

84. Andrew D, Craig AD. Spinothalamic lamina I neurons selectively sensitive to histamine: a central neural pathway for itch. Nat Neurosci. 2001;4(1):72-77. 
85. Sun Y-G, Chen Z-F. A gastrin-releasing peptide receptor mediates the itch sensation in the spinal cord. Nature. 2007;448(7154):700703.

86. Han L, Ma C, Liu Q, et al. A subpopulation of nociceptors specifically linked to itch. Nat Neurosci. 2013;16(2):174-182.

87. Sun YG, Zhao ZQ, Meng XL, Yin J, Liu XY, Chen ZF. Cellular basis of itch sensation. Science. 2009;325(5947):1531-1534.

88. Schmelz M, Schmidt R, Bickel A, Handwerker HO, Torebjork HE. Specific C-receptors for itch in human skin. J Neurosci. 1997;17(20):8003-8008.

89. Namer B, Carr R, Johanek LM, Schmelz M, Handwerker HO, Ringkamp M. Separate peripheral pathways for pruritus in man. J Neurophysiol. 2008;100(4):2062-2069.

90. Johanek LM, Meyer RA, Hartke T, et al. Psychophysical and physiological evidence for parallel afferent pathways mediating the sensation of itch. J Neurosci. 2007;27(28):7490-7497.

91. Davidson S, Zhang X, Khasabov SG, et al. Pruriceptive spinothalamic tract neurons: physiological properties and projection targets in the primate. J Neurophysiol. 2012;108(6):1711-1723.

92. Davidson S, Zhang X, Yoon CH, Khasabov SG, Simone DA, Giesler GJJ. The itch-producing agents histamine and cowhage activate separate populations of primate spinothalamic tract neurons. J Neurosci. 2007;27(37):10007-10014.

93. Mochizuki H, Sadato N, Saito DN, et al. Neural correlates of perceptual difference between itching and pain: a human fMRI study. Neuroimage. 2007;36(3):706-717.

94. Papoiu ADP, Coghill RC, Kraft RA, Wang H, Yosipovitch G. A tale of two itches: common features and notable differences in brain activation evoked by cowhage and histamine induced itch. Neuroimage. 2012;59(4):3611-3623.

95. LaMotte RH, Dong X, Ringkamp M. Sensory neurons and circuits mediating itch. Nat Rev Neurosci. 2014;15(1):19-31.

96. Ji RR. Neuroimmune interactions in itch: do chronic itch, chronic pain, and chronic cough share similar mechanisms? Pulm Pharmacol Ther. 2015;35(Supplement C):81-86.

97. Mei J. The mechanisms and perception of itch. Yale Scientific. 2011. Available from: http://www.yalescientific.org/2011/05/themechanisms-and-perception-of-itch/. Accessed January 4, 2018.

98. Alexander JO. The physiology of itch. Parasitol Today. 1986;2(12):345-351.

99. Zhao ZQ, Liu XY, Jeffry J, et al. Descending control of itch transmission by the serotonergic system via 5 -HT1A-facilitated GRP-GRPR signaling. Neuron. 2014;84(4):821-834.

100. Murota H, Katayama I. Exacerbating factors of itch in atopic dermatitis. Allergol Int. 2017;66(1):8-13.

101. Leknes SG, Bantick S, Willis CM, Wilkinson JD, Wise RG, Tracey I. Itch and motivation to scratch: an investigation of the central and peripheral correlates of allergen- and histamine-induced itch in humans. J Neurophysiol. 2007;97(1):415-422.

102. Patel T, Ishiuji Y, Yosipovitch G. Nocturnal itch: why do we itch at night? Acta Derm Venereol. 2007;87(4):295-298.

103. Lavery MJ, Stull C, Kinney MO, Yosipovitch G. Nocturnal pruritus: the battle for a peaceful night's sleep. Int J Mol Sci. 2016;17(3):425.

104. Strine TW, Chapman DP. Associations of frequent sleep insufficiency with health-related quality of life and health behaviors. Sleep Med. 2005;6(1):23-27.

105. Nocturnal pruritus: Prevalence, characteristics, and impact on ItchyQoL in a chronic itch population. J Am Acad Dermatol. 2017;76(6):AB179.
106. Warlich B, Fritz F, Osada N, et al. Health-related quality of life in chronic pruritus: an analysis related to disease etiology, clinical skin conditions and itch intensity. Dermatology. 2015;231(3):253-259.

107. Phan NQ, Blome C, Fritz F, et al. Assessment of pruritus intensity: prospective study on validity and reliability of the visual analogue scale, numerical rating scale and verbal rating scale in 471 patients with chronic pruritus. Acta Derm Venereol. 2012;92(5):502-507.

108. Millington GWM, Collins A, Lovell CR, et al. British Association of Dermatologists' guidelines for the investigation and management of generalized pruritus in adults without an underlying dermatosis, 2018. Br J Dermatol. 2018;178(1):34-60.

109. Nestler JE. Hemochromatosis and pruritus. Ann Intern Med. 1983;98(6):1026.

110. Valsecchi R, Cainelli T. Generalized pruritus: a manifestation of iron deficiency. Arch Dermatol. 1983;119(8):630.

111. Le Gall-Ianotto C, Misery L. Pruritus in hematological diseases (including aquagenic pruritus). In: Misery L, Ständer S, eds. Pruritus. Cham, Switzerland: Springer; 2016:271-281.

112. Levy C. Management of pruritus in patients with cholestatic liver disease. Gastroenterol Hepatol (NY). 2011;7(9):615-617.

113. Greenberger PA. Chronic urticaria: new management options. World Allergy Organ J. 2014;7(1):31.

114. Zhang P, Wu MX. A clinical review of phototherapy for psoriasis. Lasers Med Sci. 2017/10/24. 2018;33(1):173-180.

115. Song J, Xian D, Yang L, Xiong X, Lai R, Zhong J. Pruritus: progress toward pathogenesis and treatment. Biomed Res Int. 2018;2018:9625936.

116. Gangemi S, Quartuccio S, Casciaro M, Trapani G, Minciullo PL, Imbalzano E. Interleukin 31 and skin diseases: a systematic review. Allergy Asthma Proc. 2017;38(6):401-408.

117. Ruzicka T, Hanifin JM, Furue M, et al. Anti-interleukin-31 receptor A antibody for atopic dermatitis. N Engl J Med. 2017;376(9):826-835.

118. Nemoto O, Furue M, Nakagawa H, Shiramoto M, Hanada R, Matsuki S, et al. The first trial of CIM331, a humanized antihuman interleukin-31 receptor A antibody, in healthy volunteers and patients with atopic dermatitis to evaluate safety, tolerability and pharmacokinetics of a single dose in a randomized, double-blind, placebo-controlled study. Br J Dermatol. 2016;174(2):296-304.

119. Yosipovitch G, Ständer S, Kerby MB, et al. Serlopitant for the treatment of chronic pruritus: results of a randomized, multicenter, placebo-controlled phase 2 clinical trial. J Am Acad Dermatol. 2018;78(5):882-891.e10.

120. Heitman A, Xiao C, Cho Y, Polymeropoulos C, Birznieks G, Polymeropoulos M. Tradipitant improves worst itch and disease severity in patients with chronic pruritus related to atopic dermatitis. J Am Acad Dermatol. 2018;79(3):AB300.

121. Beck LA, Thaci D, Hamilton JD, et al. Dupilumab treatment in adults with moderate-to-severe atopic dermatitis. $\mathrm{N} \mathrm{Engl} \mathrm{J} \mathrm{Med.}$ 2014;371(2):130-139.

122. Odhiambo JA, Williams HC, Clayton TO, Robertson CF, Asher MI; ISAAC Phase III Study Group. Global variations in prevalence of eczema symptoms in children from ISAAC Phase Three. J Allergy Clin Immunol. 2009;124(6):1251-8.e23.

123. Dalgard FJ, Gieler U, Tomas-Aragones L, et al. The psychological burden of skin diseases: a cross-sectional multicenter study among dermatological out-patients in 13 European countries. J Invest Dermatol. 2015;135(4):984-991. 